\title{
Primary production in the Yellow Sea determined by ocean color remote sensing
}

\author{
SeungHyun Son ${ }^{1,4, *}$, Janet Campbell ${ }^{1}$, Mark Dowell ${ }^{2}$, Sinjae Yoo $^{3}$, Jaehoon Noh $^{3}$ \\ ${ }^{1}$ Ocean Process Analysis Laboratory, University of New Hampshire, Durham, New Hampshire 03824, USA \\ ${ }^{2}$ Inland and Marine Waters Unit, Joint Research Centre, TP 272, I21020 Ispra, Italy \\ ${ }^{3}$ Korea Ocean Research and Development Institute, PO Box 29, Ansan 425-600, South Korea \\ ${ }^{4}$ Present address: School of Marine Sciences, University of Maine, Orono, Maine 04469-5741, USA
}

\begin{abstract}
The Yellow Sea is a shelf sea surrounded by the Korean peninsula and the eastern coast of China. The bordering countries derive a substantial share of their food from fishing in these coastal waters. Synoptic maps of water-column integrated primary production in May and September were derived using a primary production algorithm applied to ocean color satellite data from the Yellow Sea from 1998 to 2003. The middle of the Yellow Sea (MYS) had higher levels of primary production in May and September than the shallower $(<50 \mathrm{~m})$ areas off the coasts of Korea and China. Although the coastal areas had high phytoplankton biomass, lower levels of primary production were caused by high turbidity arising from strong tides and shallow depths. Lower turbidity in the central part of the Yellow Sea allows light necessary for primary production to penetrate deeper into the water column. The mean daily integrated primary production in the MYS was $947 \mathrm{mg} \mathrm{C} \mathrm{m}^{-2} \mathrm{~d}^{-1}$ in May and $723 \mathrm{mg} \mathrm{C} \mathrm{m}^{-2} \mathrm{~d}^{-1}$ in September. The mean values in Chinese and Korean coastal waters were 590 and $589 \mathrm{mg} \mathrm{C} \mathrm{m}^{-2} \mathrm{~d}^{-1}$ in May, and 734 and $553 \mathrm{mg} \mathrm{C} \mathrm{m}^{-2} \mathrm{~d}^{-1}$ in September, respectively. Our computation of daily total primary production for the entire Yellow Sea was $19.7 \times 10^{4} \mathrm{t} \mathrm{C} \mathrm{d}^{-1}$ in May, and $15.8 \times 10^{4} \mathrm{t} \mathrm{C} \mathrm{d}^{-1}$ in September.
\end{abstract}

KEY WORDS: Primary production · Phytoplankton · Ocean color · SeaWiFS · Yellow Sea

\section{INTRODUCTION}

Coastal waters play an important role as an origin of global food resources. Although the coastal ocean occupies only $8 \%$ of the ocean surface, about $90 \%$ of the world's commercial fishes are caught in coastal waters (Pernetta \& Milliman 1995). Primary production comprises the basis of marine food webs and is an important mediator of carbon flux in the ocean. Coastal primary production has been estimated to contribute 14 to $25 \%$ of the global oceanic primary production (Longhurst et al. 1995, Pernetta \& Milliman 1995).

The Yellow Sea is a shelf sea surrounded by the Korean peninsula and the eastern coast of China, with a mean depth of $44 \mathrm{~m}$ and maximum depth of $103 \mathrm{~m}$. It is affected by strong tidal currents and freshwater discharges from the Changjiang (Yangtze) River, the largest river in Asia. The Kuroshio Current, character- ized by comparatively high-temperature and saline waters, also influences the southeast area of the Yellow Sea.

There have been many studies of phytoplankton primary production based on field measurements in the Yellow Sea (Choi \& Shim 1986, Choi 1991, Kang et al. 1992, Choi et al. 1995, Wu et al. 1995, Yoo \& Shin 1995). However, as these studies were temporally and spatially restricted, it is not possible to estimate primary production for the entire Yellow Sea based on these measurements alone. Ocean-color data are presently the only means of determining phytoplankton chlorophyll concentration on a basin or global scale; however, some problems still remain to be solved (Balch et al. 1992, Sathyendranath \& Platt 1993). Models based on remotely sensed chlorophyll a $(\mathrm{chl} a)$ concentration allow the estimation of ocean primary production on both basin and global scales (Platt et al. 1991, Balch et al. 1992, Antoine et al. 1995, Long- 
hurst et al. 1995, Antoine \& Morel 1996, Behrenfeld \& Falkowski 1997, Hoepffner et al. 1999).

Standard algorithms for primary production rely on remotely sensed chl a concentration, light attenuation, surface irradiance, and/or sea-surface temperature. Algorithms also require information not accessible by remote sensing, such as the vertical distribution of phytoplankton biomass and photosynthetic parameters. To handle non-uniformity of phytoplankton biomass in thermally stratified waters, it has been customary to relate the remotely sensed chlorophyll concentration at the surface to the vertical profile of phytoplankton biomass (Lewis et al. 1983, Platt et al. 1988, Morel \& Berthon 1989). A shifted Gaussian distribution has been proposed to derive biomass profiles (Platt et al. 1988b).

There are 2 main approaches to estimating photosynthetic parameters, but both methods have weaknesses (Platt et al. 1995). One is to derive the required parameters as a function of environmental variables such as sea-surface temperature (Behrenfeld \& Falkowski 1997 , Gong \& Liu 2003). The other is to assign the parameters based on their location and season from an existing database for biogeochemical provinces (Platt \& Sathyendranath 1988, Longhurst et al. 1995, Sathyendranath et al. 1995, Hoepffner et al. 1999). The latter approach was applied to data from the Yellow Sea in the present study.

We used the primary production algorithm of Platt \& Sathyendranath (1988) to estimate primary production in the Yellow Sea. We first partitioned the Yellow Sea into 3 subregions based on bathymetry and physical features, and used in situ measurements taken in these subregions in May and September between 1992 and 1998 to parameterize the algorithm. We explored sev- eral ways of estimating the diffuse attenuation coefficient, $k_{\mathrm{d}}$, and investigated whether it was necessary to model the vertical biomass profile. The resulting maps of primary production calculated from the remotely sensed data provide the first synoptic views of primary production in the Yellow Sea.

\section{MATERIALS AND METHODS}

In situ data. Cruise data on phytoplankton biomass and primary production in the Yellow Sea (from 32 to $37^{\circ} \mathrm{N}$ and 122 to $127^{\circ} \mathrm{E}$ ) were available from only 2 months from 6 cruises conducted between 1992 and 1998, namely May and September (Table 1). Parameters from 141 photosynthesis-light ( $P$ versus $E ; P-E$ ) curves were available from 6 different cruises between 1992 and 1998. Of these, $93 P$-E parameters were obtained at the surface, 37 between 10 and $30 \mathrm{~m}$, and 11 between 40 and $75 \mathrm{~m}$. All $P$-E measurements were based on ${ }^{14} \mathrm{C}$ methods (Steemann Nielsen 1952). Water samples were incubated for $2 \mathrm{~h}$ on deck under screens simulating 9 to 10 light levels between 0 and $100 \%$ surface photosynthetically available radiation (PAR). The $P$-E data were then fitted as described by Platt et al. (1980). For further details, see Choi et al. (1995) and Park (2000). There were $86 \mathrm{chl}$ a fluorescence profiles available from the 6 cruises between 1992 and 1998. These were measured with a CTD-SBE 25, and calibrated with discrete chl a measured fluorometrically (Turner Design).

Estimates of daily water-column primary production were made only at 37 stations on the September 1992 cruise of Choi et al. (1995) (Fig. 1b). Water-column

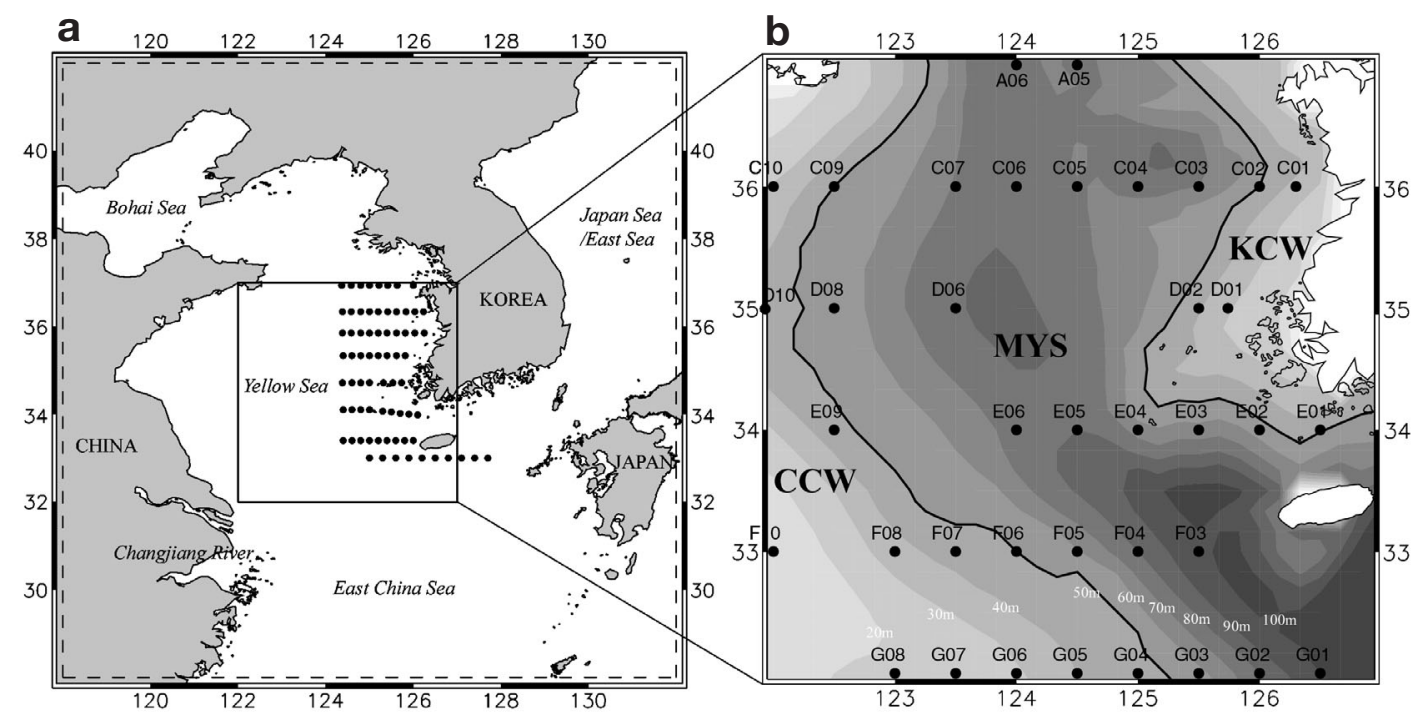

Fig. 1. Geography of the study area. The Yellow Sea was divided into 3 sub-regions using bathymetry and physical features. CCW: Chinese Coastal Waters, MYS: Mid-Yellow Sea, and KCW: Korean Coastal Waters. The serial oceanographic stations of KODC (Korea Oceanographic Data Center) for Secchi depth data are shown in (a) and the observatory stations for primary production of the Yellow Sea cruise in September 1992 (Choi et al. 1995) are shown in (b) 
Table 1. Sources of data for the chlorophyll profiles and $P$-E parameters in the Yellow Sea ( 32 to $37^{\circ} \mathrm{N}$ and 122 to $127^{\circ} \mathrm{E}$ ). Total number is 141 stations. COPEX: Coastal Ocean Process Experiment cruise; LME: Yellow Sea Large Marine Ecosystem cruise; KORDI: Korea Ocean Research and Development Institut, South Korea

\begin{tabular}{|c|c|c|c|c|}
\hline $\begin{array}{l}\text { Cruise } \\
\text { name }\end{array}$ & Source & Period & $\begin{array}{c}\text { No. of } \\
P-E \\
\text { parameters }\end{array}$ & $\begin{array}{l}\text { No. of } \\
\text { chl } a \\
\text { profiles }\end{array}$ \\
\hline YS-9210 & $\begin{array}{l}\text { Choi et al. } \\
\text { (1995) }\end{array}$ & $\begin{array}{c}17 \text { Sep- } \\
2 \text { Oct, } 1992\end{array}$ & 38 & 38 \\
\hline COPEX & KORDI & $\begin{array}{c}29 \text { Aug- } \\
5 \text { Sep, } 1994\end{array}$ & 11 & 10 \\
\hline COPEX & KORDI & $\begin{array}{c}26 \text { Apr- } \\
6 \text { May, } 1995\end{array}$ & 24 & 9 \\
\hline LME & KORDI & 20-24 May, 1996 & 12 & 11 \\
\hline LME & KORDI & 20-31 May, 1997 & 36 & 14 \\
\hline LME & KORDI & 15-19 May, 1998 & 20 & 4 \\
\hline Total & & & 141 & 86 \\
\hline
\end{tabular}

integrated primary production could not be estimated for the other stations because of a lack of light profile or diffuse attenuation data. The daily water-column primary production at these 37 stations was compared with satellite-derived primary production, even though the 2 data sets did not coincide temporally.

Cruise data on temperature, salinity, and transparency (Secchi depth) at 71 stations in the southeast Yellow Sea were obtained from the Korea Oceanographic Data Center (KODC) (Fig. 1a). These data were from oceanographic surveys carried out at 2 mo intervals (February, April, June, August, October, and December) by the National Fisheries Research and Development Institute (NFRDI). The Secchi depth (SD) data from 1998 to 2002 (coinciding with the time period of the satellite data) were used to estimate the diffuse attenuation coefficient for PAR as explained below.

Satellite data. SeaWiFS Level 1a Version 4 data from 1998 to 2003 for the Yellow Sea were obtained from the NASA Goddard Space Flight Center (GSFC). The daily SeaWiFS data, with a spatial resolution of $1 \times 1 \mathrm{~km}^{2}$, were processed from Level 0 to 2 and remapped using the SeaWiFS Data Analysis System (SeaDAS) Version 4.4 software (NASA GSFC). The standard algorithms of SeaDAS were used for the atmospheric correction. After eliminating images acquired on cloudy days, there remained 1358 images of the Yellow Sea from 1998 to 2003, including 236 images in the months of May and September.

The standard algorithm for the SeaWiFS chl a concentration is based on Case 1 waters, defined as those waters where phytoplankton pigments are the sole factor determining the color of the water (Morel \& Prieur 1977). Although the middle of the Yellow Sea may be characterized as Case 1 waters in warm months of the year (spring to fall), large areas of the Yellow Sea are
Case 2 waters. In particular, colored dissolved organic matter and suspended sediments also affect the water color in shallow areas influenced by strong tidal mixing and river discharge. We used a local empirical algorithm of chl a concentration for the Yellow Sea developed by Ahn (2004):

$$
\text { Chl } a=1.05 \times\left(\frac{\operatorname{Rrs} 490}{\operatorname{Rrs} 555}\right)^{-1.70}
$$

where Rrs490 and Rrs555 are remote-sensing reflectance at 490 and $555 \mathrm{~nm}$, respectively. The algorithm was developed using (1) measured remote-sensing reflectance from the Dual UV/VNIR spectroradiometer in the Korean Seas and (2) measured chlorophyll concentrations. Although it does not explicitly account for other constituents affecting water color, it was tailored for the optical properties of the Yellow Sea.

Primary production model. Since there were no spectral light or phytoplankton absorption measurements available from the cruises, we used a spectrallyintegrated primary production model (Platt \& Sathyendranath 1988). Daily depth-integrated primary production (IPP) was derived using the equation:

$$
\mathrm{IPP}=\int_{t_{1}}^{t_{2}} \int_{0}^{z_{\mathrm{eu}}} \frac{B(z) \cdot \alpha^{\mathrm{B}} \cdot E(z, t)}{\sqrt{1+\left(\alpha^{\mathrm{B}} \cdot E(z, t) / P_{\mathrm{m}}^{\mathrm{B}}\right)^{2}}} \mathrm{~d} z \cdot \mathrm{d} t
$$

where $B(z)$ is the chl a biomass at depth $z_{i} \alpha^{\mathrm{B}}$ is the initial slope of the $P^{\mathrm{B}}$ versus $E$ curve; $E(z, t)$ is PAR at depth $z$ and time $t_{i} P_{\mathrm{m}}^{\mathrm{B}}$ is the assimilation number; $t_{1}$ and $t_{2}$ are the times of sunrise and sunset; and $Z_{\text {eu }}$ is the euphotic depth. The vertical PAR profile is given by $E(z, t)=E(0, t) \times \exp \left(-k_{\mathrm{d}} \times z\right)$ were $E(0)$ is PAR incident on the surface, and $k_{\mathrm{d}}$ is the diffuse attenuation coefficient for PAR. The input parameters used in the primary production model (Eq. 2) are described in the following sections.

Biomass profile (deep chlorophyll maximum [DCM] model). The Yellow Sea was partitioned into wellmixed and stratified waters using a relationship between water-leaving radiance at $670 \mathrm{~nm}$ from SeaWiFS and model-based temperature profiles (S. Son et al. unpubl. data). We assumed that the biomass profile $B(z)$ was uniform in well-mixed waters and nonuniform in stratified waters.

The shifted Gaussian distribution model (Platt et al. 1988, Sathyendranath \& Platt 1989) was used to describe the biomass profile:

$$
B(z)=B_{0}+\frac{h}{\sigma \sqrt{2 \pi}} \exp \left[-\frac{\left(z-z_{\mathrm{m}}\right)^{2}}{2 \sigma^{2}}\right]
$$

where $B_{0}$ is a background biomass $\left(\mathrm{mg} \mathrm{m}^{-3}\right) ; z_{\mathrm{m}}$ is the depth of the chlorophyll maximum $(\mathrm{m}) ; \sigma$ is a measure of the thickness or vertical spread of the peak $(\mathrm{m}) ; h$ is 
the total biomass above the background $\left(\mathrm{mg} \mathrm{m}^{-2}\right)$; and peak height above the baseline is given by $\mathrm{H}=$ $h /(\sigma \sqrt{2 \pi})$. Parameters were estimated by fitting this model to the 86 chlorophyll profiles (Table 1).

PAR profile. The PAR product of SeaWiFS was used for the incident surface irradiance. Unfortunately, there were very few light measurements in the Yellow Sea available for this study. Since large areas of the Yellow Sea are affected by colored dissolved organic matter and suspended sediments, the diffuse attenuation model of Sathyendranath \& Platt (1988), which is for Case 1 waters (i.e. based on chlorophyll), was not applicable to the Yellow Sea.

The SD data obtained from the NFRDI provided the best source of information about light extinction in these coastal Korean waters. In addition, there were 17 stations from the primary productivity cruises (Table 1) where both $K_{\mathrm{d}}$ and SD had been measured. The $k_{\mathrm{d}}$ values were derived from measurements by a PAR sensor attached to the CTD-SBE 25. The relationship between $\mathrm{SD}$ and $k_{\mathrm{d}}$ for these stations is shown in Fig. 2. Also shown is the relationship $k_{\mathrm{d}}=1.44 / \mathrm{SD}$ (Kirk 1994), which appears to be in reasonable agreement with the data. Therefore, we used this relationship to derive $k_{\mathrm{d}}$ from the NRFDI SD data.

The primary production algorithm requires $k_{\mathrm{d}}$ at every pixel in the image. Therefore, we explored the relationship between the SD and SeaWiFS K490 and nLw555 products. The SD data in the period between 1998 and 2002 were matched with SeaWiFS data obtained within $1 \mathrm{~d}$ of the in situ measurement. There were 300 match-up pairs, including 149 made on the same day.

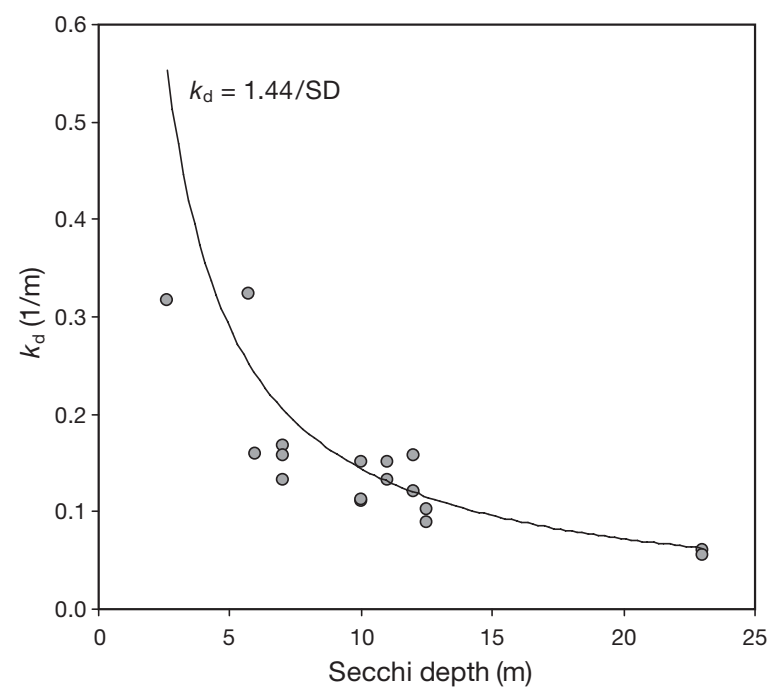

Fig. 2. Scatter plots of measured diffuse attenuation derived from PAR in the water column versus measured Secchi depth (SD) at 17 stations in the Yellow Sea. The line of $k_{\mathrm{d}}=1.44 / \mathrm{SD}$ is also drawn on the scatter plots

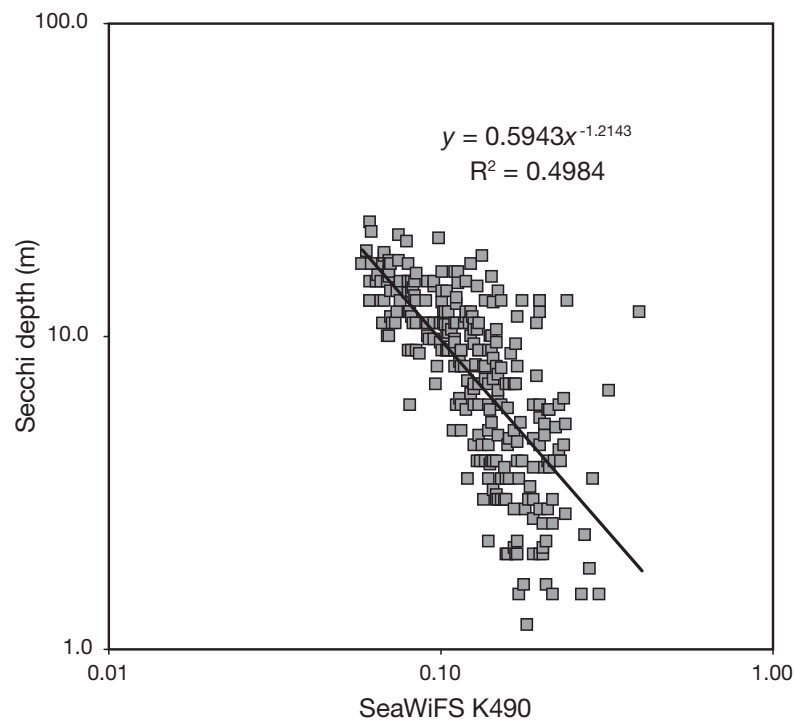

Fig. 3. Secchi depth data obtained in the southeastern Yellow Sea from KODC were plotted against the SeaWiFS K490 product (note log scale on both axes) in 286 stations during the periods of 1998 to 2002 (match up data is $1 \mathrm{~d}$ before to $1 \mathrm{~d}$ after)

The match-up SD measurements were regressed against SeaWiFS K490 and nLw555 products (Figs. 3 \& 4). The SD data did not correlate as well to the K490 data $\left(\mathrm{r}^{2}=0.5\right.$, Fig. 3) as they did to the nLw555 data $\left(\mathrm{r}^{2}=0.78\right.$, Fig. 4). Therefore, we used the derived power-law relationship $\mathrm{SD}=6.4023 \times(\mathrm{nLw} 555)^{-0.7269}$ to estimate $\mathrm{SD}$, which was then converted to diffuse attenuation coefficient by the relationship $k_{\mathrm{d}}=1.44 \mathrm{SD}$ (Kirk 1994).

The euphotic depth $\left(Z_{\text {eu }}\right)$ was defined as the depth at which PAR is $1 \%$ of the surface PAR. Accordingly, the euphotic depth is given by $4.6 / k_{\mathrm{d}}$ with the assumption that $k_{\mathrm{d}}$ is approximately constant with depth (Kirk 1994). Given the relationship with SD, the euphotic depth was then given by $Z_{\text {eu }}=3.2 \times \mathrm{SD}$.

Photosynthetic parameters. Two approaches to estimate the photosynthetic parameters for primary production were mentioned above. To consider the first approach, we investigated the relationship between sea surface temperature and the photosynthetic parameter $\left(P_{\mathrm{m}}^{\mathrm{B}}\right)$ (Behrenfeld \& Falkowski 1997), but found no apparent relationship in our data set (Fig. 5). Thus, we chose the second approach whereby parameters are based on average properties measured within biogeochemical provinces (Longhurst et al. 1995, Platt et al. 1995, Sathyendranath et al. 1995).

Accordingly, the Yellow Sea (between 32 and $37^{\circ} \mathrm{N}$, 122 and $127^{\circ} \mathrm{E}$ ) was divided into 3 subregions based on bathymetry (Fig. 1b): (1) the Chinese Coastal Waters (CCW) and (2) the Korean Coastal Waters (KCW) shallower than $50 \mathrm{~m}$, and (3) the central part of the Yellow Sea (MYS) deeper than $50 \mathrm{~m}$. Ning et al. (1998) parti- 


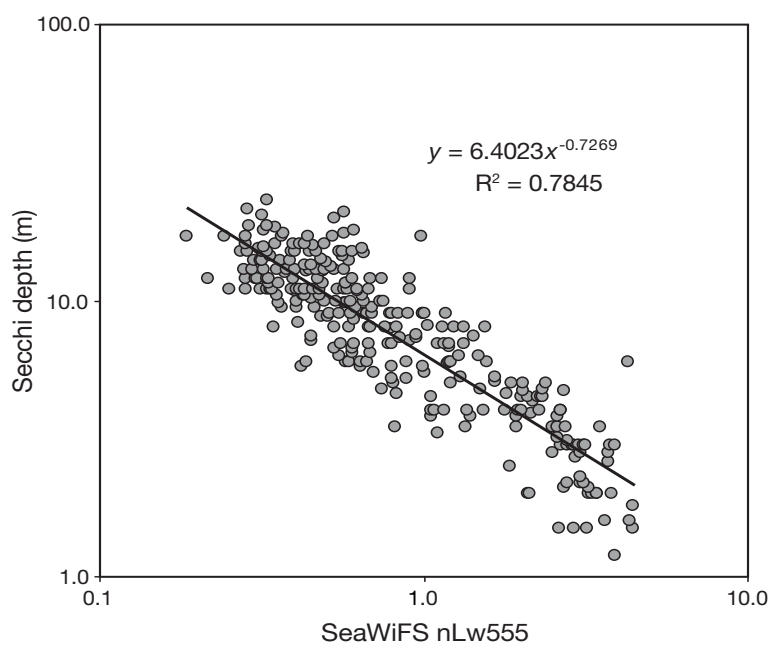

Fig. 4. Secchi depth data obtained in the southeastern Yellow Sea from KODC were plotted against the SeaWiFS waterleaving radiances at $555 \mathrm{~nm}$ in 286 stations during the periods of 1998 to 2002 (match up data is $1 \mathrm{~d}$ before to $1 \mathrm{~d}$ after). Note log scale on both axes

tioned the major water masses in the Yellow Sea in a similar manner. The averages of measured parameters within each region were used in the algorithm.

Oceanographic subregions. The 2 coastal regions, $\mathrm{CCW}$ and KCW, are affected by tidal mixing and freshwater discharge. The CCW region is strongly influenced by discharge from the Changjiang River which averages about $2.9 \times 10^{4} \mathrm{~m}^{3} \mathrm{~s}^{-1}(\mathrm{~S}$. Riedlinger \& R. Preller unpubl. data). The Han and Keum rivers, with a mean annual discharge of about $1.0 \times 10^{3} \mathrm{~m}^{3} \mathrm{~s}^{-1}$ (Schubel et al. 1984), affect the KCW region. The southern part of the $\mathrm{KCW}$ is tidally mixed year round, whereas the CCW remains stratified due to the buoyant Changjiang River plume. The Korean Coastal Current flows southward along the southern edge of the Korean Peninsula year round (Mask et al. 1998). In the CCW, the Yellow Sea Cold Water flows southward year round along the Chinese coast, and the Chang-

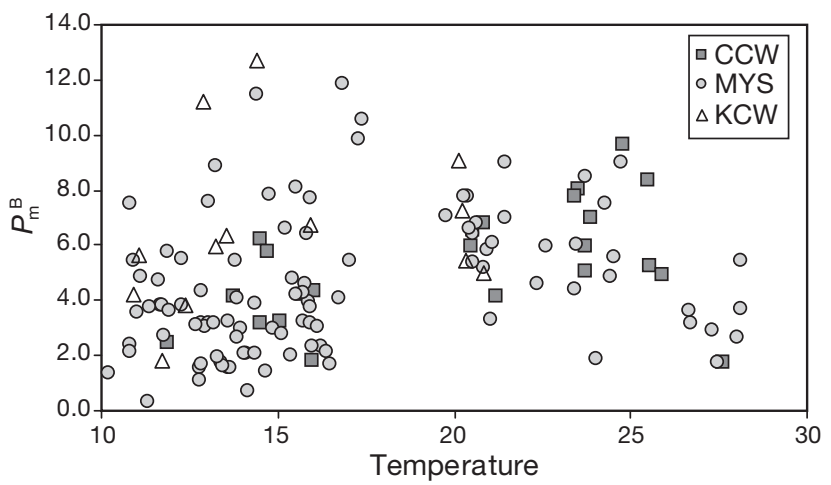

Fig. 5. Scatter plots of temperature $\left({ }^{\circ} \mathrm{C}\right)$ and the photosynthetic parameter $\left(P_{\mathrm{m}}^{\mathrm{B}}\right)$ in 3 different regions (CCW: Chinese Coastal Waters, MYS: Middle of Yellow Sea waters, and KCW: Korean Coastal Waters) in the Yellow Sea jiang Coastal Current, related to the Changjiang discharge, flows southward along the Chinese coast in winter and eastward in summer (Beardsley et al. 1983, 1985, Mask et al. 1998, Su 1998).

The southern part of the MYS is affected by the warm and saline waters of the Kuroshio Current; the Yellow Sea Warm Current, which is a branch of the Kuroshio Current, flows northward through this central region. In the northern part of the MYS, the Yellow Sea Cold Water is formed by strong vertical mixing in winter, and traces remain during the summer.

\section{RESULTS}

The means and standard deviations of the photosynthetic parameters for the 3 subregions in May and September are listed in Table 2 and shown in Fig. 6. The assimilation numbers $\left(P_{\mathrm{m}}^{\mathrm{B}}\right)$ were on average higher in September than in May in all regions, and higher in the KCW than in the other 2 regions during both months. The light utilization efficiency $\left(\alpha^{\mathrm{B}}\right)$ was also higher in September than in May in all 3 regions, with the highest average values occurring in the MYS. While the error bars (95\% confidence intervals) for both $P_{\mathrm{m}}^{\mathrm{B}}$ and $\alpha^{\mathrm{B}}$ are reasonably small in MYS, those in the coastal regions are very high, especially in the $\mathrm{KCW}$, due to the small number of observations in those locations.

The Gaussian parameters derived from fitting Eq. (3) to the measured chlorophyll profiles were averaged within each month in the 3 subregions. Chlorophyll profiles based on mean parameters are shown in Fig. 7, along with the mean parameters. A deep chlorophyll maximum existed in all 3 regions in both months, but was much more pronounced in May than in September. The 2 coastal regions had generally higher chlorophyll levels, a shallower $z_{\mathrm{m}}$, and smaller $h$ and $\sigma$ compared with the MYS region. In KCW and MYS, $z_{m}$ was on average deeper in May than in September, whereas in the CCW, $z_{\mathrm{m}}$ was slightly shallower in May than in September. Both the surface chlorophyll concentration

Table 2. P-E parameters for the 3 regions of the Yellow Sea. STD: standard deviation

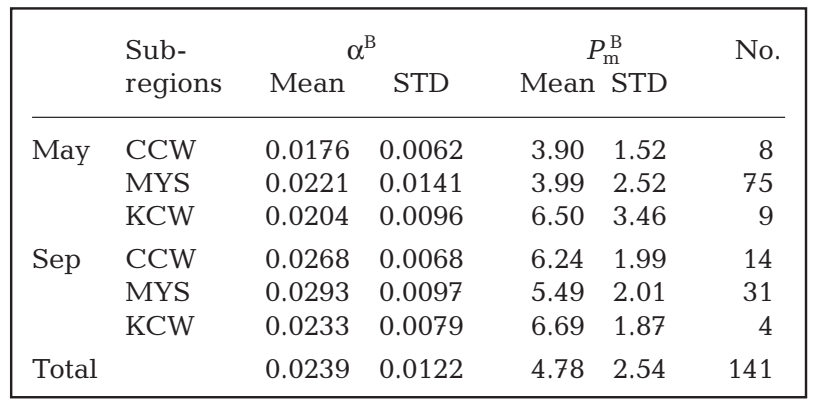



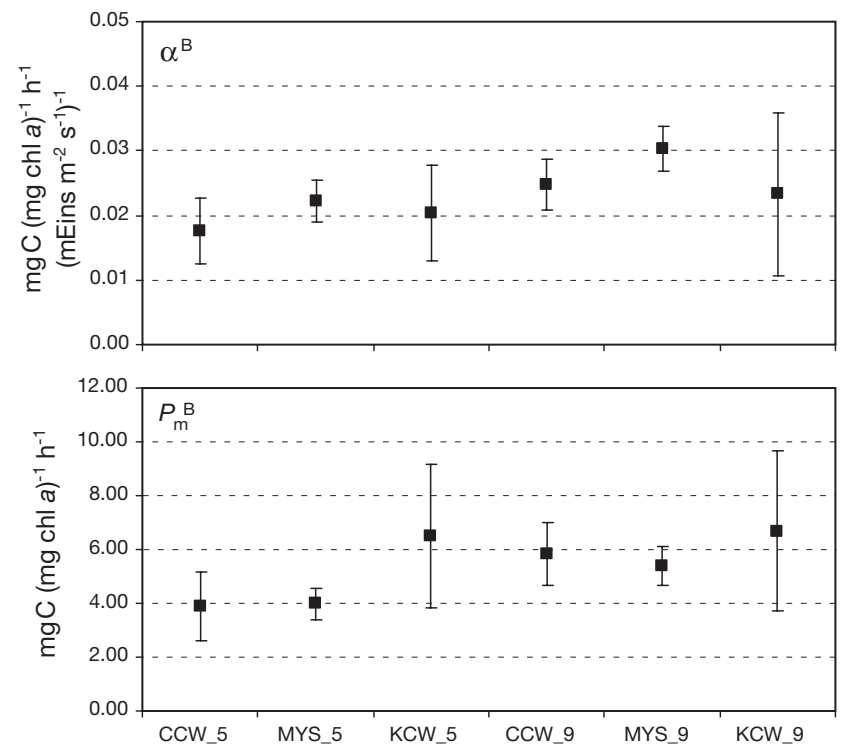

Fig. 6. Mean values of the light utilization efficiency $\left(\alpha^{\mathrm{B}}\right)$ and the photosynthetic parameter $\left(P_{\mathrm{m}}{ }^{\mathrm{B}}\right)$ in 3 different regions (CCW, MYS, and KCW) in May (first 3 points from the left) and December (first 3 points from the right) with $95 \%$ confidence intervals
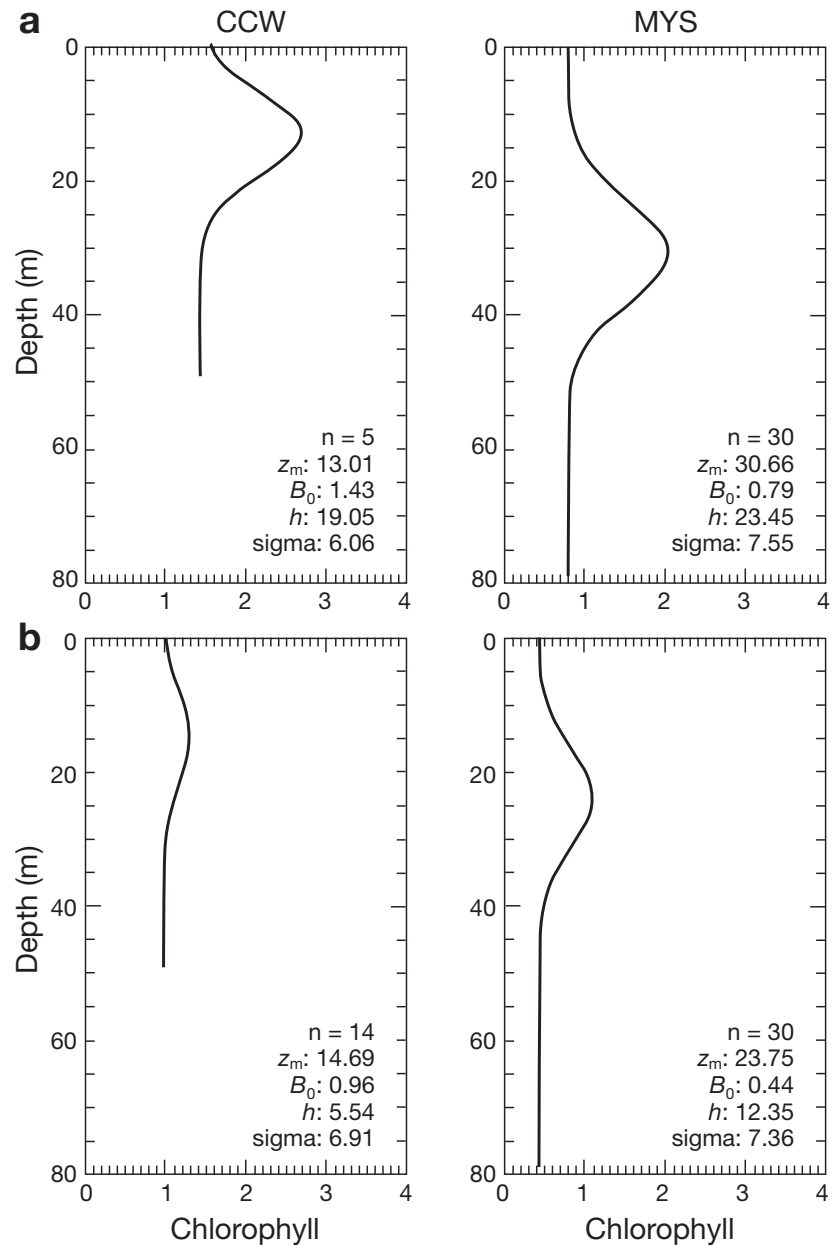

and the integrated chlorophyll (to $50 \mathrm{~m}$ in $\mathrm{KCW}$ and $\mathrm{CCW}$, and to $80 \mathrm{~m}$ in MYS) were higher in May than in September.

To test the effect of the non-uniform biomass profile on primary production, we compared primary production calculated using a uniform biomass profile (equal to the surface chlorophyll) with the integrated primary production measured at the 37 stations in September 1992 (Choi et al. 1995). The latter took into account the non-uniform chlorophyll profiles at each station. With the exception of the biomass profile $B(z)$, the same measured variables were used in both calculations. The scatter plot of non-uniform-biomass primary production (PP2) versus uniform-biomass primary production (PP1) is shown in Fig. 8. Assuming uniform biomass profiles, primary production was underestimated by an average of $15.6 \%$ (and as much as 39\%) at stations deeper than $50 \mathrm{~m}$. In the shallower stations $(<50 \mathrm{~m})$, the error was on average only $7 \%$.

Since the input parameters $\left(P_{\mathrm{m}}^{\mathrm{B}}, \alpha^{\mathrm{B}}\right.$ and DCM $)$ were based on measurements made only in May and September (Table 1), we applied the algorithm only to May and September SeaWiFS data. Monthly composites of
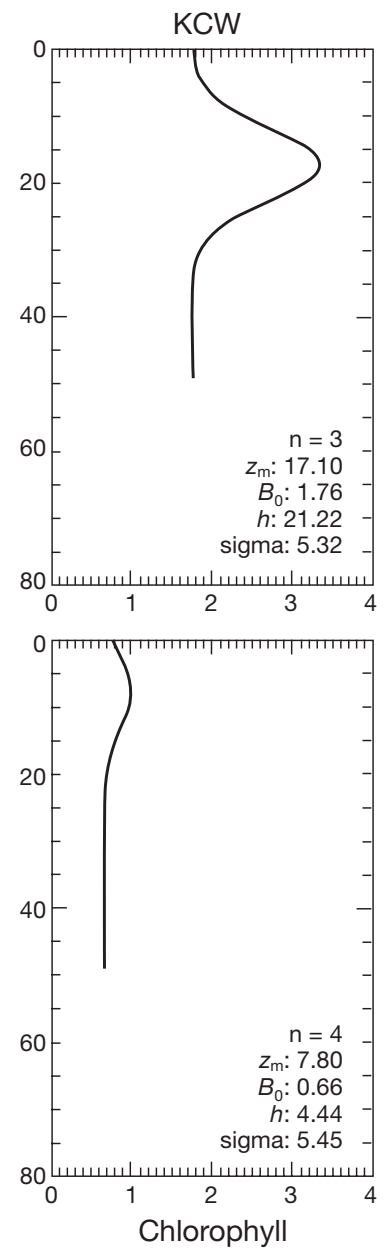

Fig. 7. Mean fitted biomass (chlorophyll) profiles for the 3 sub-regions of the Yellow Sea in (a) May and (b) September. Number of data used (n) and 4 parameters of DCM (deep chlorophyll maximum) model are shown in each graph. $B_{0}$ : background biomass (mg $\left.\mathrm{m}^{-3}\right) ; z_{\mathrm{m}}$ : depth of chorophyll maximum $(\mathrm{m})$; $h$ : total biomass above the background $\left(\mathrm{mg} \mathrm{m} \mathrm{m}^{-2}\right) ; \sigma$ : measure of the thickness or vertical spread of the chlorophyll peak (m) 


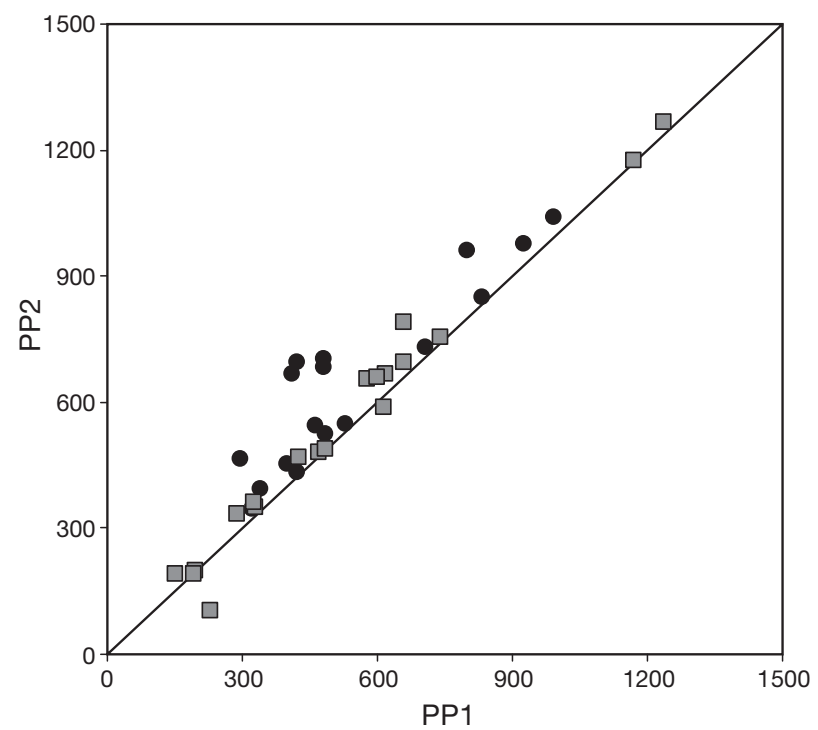

Fig. 8. Scatter plots of primary production calculated using a uniform biomass profile (PP1) versus primary production using non-uniform biomass profile (PP2) at 37 stations of the Yellow Sea cruise in September, 1992 (Choi et al. 1995). Squares indicate primary production in deeper area $(>50 \mathrm{~m})$ and circles in the shallower areas $(<50 \mathrm{~m})$

the input data PAR, $k_{\mathrm{d}}$ and chl $a$, from 1998 to 2003, and their 6 year averages, are shown in Fig. 9, and the monthly composite primary production images for these years are shown in Fig. 10. Year-to-year variations of the means in each subregion are shown in Fig. 11.

The overall spatial distribution of PAR was uniform in May, but increased from south to north in September. On average, PAR was $26 \%$ higher in May (6 year mean of 58.3 to 58.6 Ein $\mathrm{m}^{-2} \mathrm{~d}^{-1}$ ) than in September (6 yr

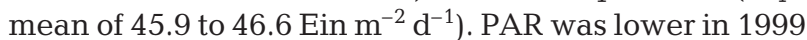
and 2003 in both months compared with other years.

The $k_{\mathrm{d}}$ images were derived from the SeaWiFS nLw555 data using methods described above. The spatial distribution of the 6 year average of $k_{\mathrm{d}}$ in May and September were similar. In both months, high values of $k_{\mathrm{d}}$ were found near the Kyunggi Bay, the southwestern coastal regions of Korea, the Shandong peninsula, and the Changjiang River, while $k_{\mathrm{d}}$ was lower in the middle of the Yellow Sea. However, a comparatively high $k_{\mathrm{d}}$ patch appeared in the middle of the Yellow Sea in May. The mean value of $k_{\mathrm{d}}$ based on the 6 year composites for May ranged from 0.33 to $0.38 \mathrm{~m}^{-1}$ in the coastal regions (CCW and $\mathrm{KCW}$ ), to $0.13 \mathrm{~m}^{-1}$ in the central regions of the Yellow Sea (MYS). The mean value of $k_{\mathrm{d}}$ in September in the central Yellow Sea was similar to that in May $\left(0.12 \mathrm{~m}^{-1}\right)$, but September values were slightly lower in the coastal regions $\left(0.30 \mathrm{~m}^{-1}\right)$ compared to May. The interannual variability of $k_{\mathrm{d}}$ was more pronounced in the coastal regions compared with the MYS.
Spatial patterns of chl a were similar in both months, with higher chl $a$ in coastal areas and near the Changjiang River, and relatively low values in the central Yellow Sea. The 6 year mean chl a was slightly higher in May $\left(0.95 \mathrm{mg} \mathrm{m}^{-3}\right)$ than in September $\left(0.93 \mathrm{mg} \mathrm{m}^{-3}\right)$, and chl a was slightly higher in the KCW (1.74 and $1.81 \mathrm{mg} \mathrm{m}^{-3}$ in May and September, respectively) than in the CCW (1.61 and $1.46 \mathrm{mg} \mathrm{m}^{-3}$ in May and September, respectively). In the MYS, chl a was slightly lower in May $\left(0.70 \mathrm{mg} \mathrm{m}^{-3}\right)$ than in September $\left(0.77 \mathrm{mg} \mathrm{m}^{-3}\right)$. A patch of significantly higher chl a appeared in the central Yellow Sea in each May image. This patch, located in the vicinity of a Korean dump site used since 1992, varied in size and concentration from year to year. The patch spread widely in 1999 and had the highest chl a levels in 2001.

The depth-integrated daily primary production for May and September are shown in Fig. 10, and the means calculated for each subregion are listed in Table 3. Primary productivity throughout the Yellow Sea was higher in May than in September, and higher in the MYS than in the coastal regions. In the MYS, the 6 year mean primary production was $947 \mathrm{mg} \mathrm{C} \mathrm{m}^{-2} \mathrm{~d}^{-1}$ in May and $723 \mathrm{mg} \mathrm{C} \mathrm{m} \mathrm{m}^{-2} \mathrm{~d}^{-1}$ in September; in the $\mathrm{KCW}$, the mean was $734 \mathrm{mg} \mathrm{C} \mathrm{m}^{-2} \mathrm{~d}^{-1}$ in May and $554 \mathrm{mg} \mathrm{C} \mathrm{m}^{-2} \mathrm{~d}^{-1}$ in September. There was almost no difference between May and September in the CCW, with averages of 590 and $589 \mathrm{mg} \mathrm{C} \mathrm{m} \mathrm{m}^{-2} \mathrm{~d}^{-1}$, respectively. Interannual variability can be clearly seen in Figs. $10 \& 11$. The daily primary production estimated for the entire Yellow Sea was $19.7 \times 10^{4} \mathrm{t} \mathrm{C} \mathrm{d}^{-1}$ in May and $15.8 \times 10^{4} \mathrm{t} \mathrm{C} \mathrm{d}^{-1}$ in September.

The measured IPP at 37 stations in September 1992 were compared (1) to the range of values at the same locations in the monthly composite satellite data of each year, and (2) to the 6 year averages (Fig. 12). At about two-thirds of the stations, the measured IPP fell within the range of the satellite-derived values. Exceptions occurred along the C-line (Fig. 1b) where the satellite values were much higher than the measured IPP, and at Stn F07, where the satellite values were much lower than the measured value.

\section{DISCUSSION AND CONCLUSION}

We estimated that an assumption of a uniform biomass profile would have resulted in an underestimation of primary production by $15 \%$ in the deep regions $(>50 \mathrm{~m})$ and $7 \%$ in the 2 shallower coastal regions. These results are consistent with results reported by others. Platt et al. (1991) determined that a uniform biomass profile would underestimate integral production by about $20 \%$ in the North Atlantic. Siswanto et al. (2004) found that primary production derived from a 

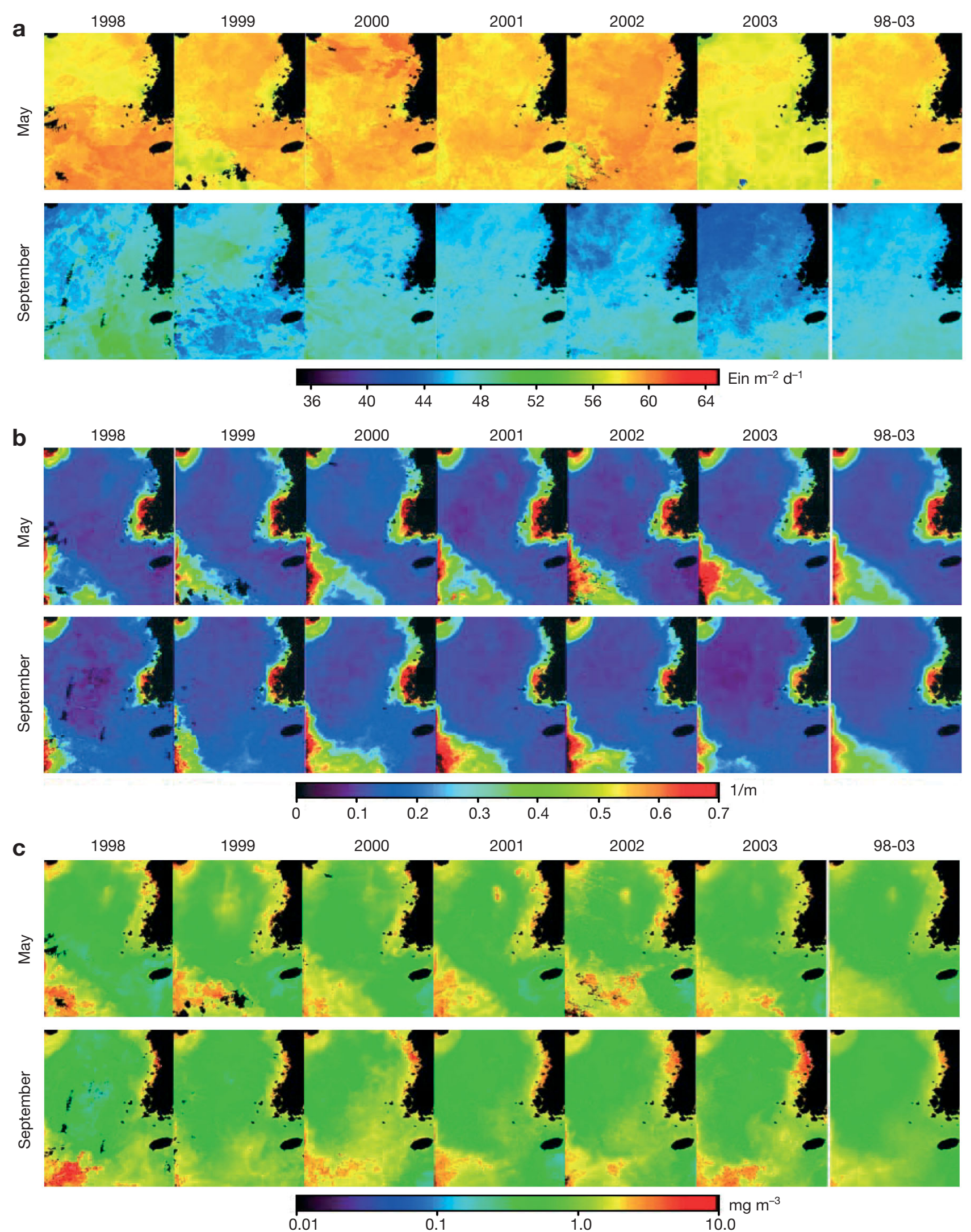

Fig. 9. Monthly composite SeaWiFS images from 1998 to 2003 in May and September as well as 6-year composite images (9803 panels) of (a) PAR, (b) diffuse attenuation $\left(k_{d}\right)$ derived from nLw555, (c) chlorophyll derived from Ahn's algorithm 


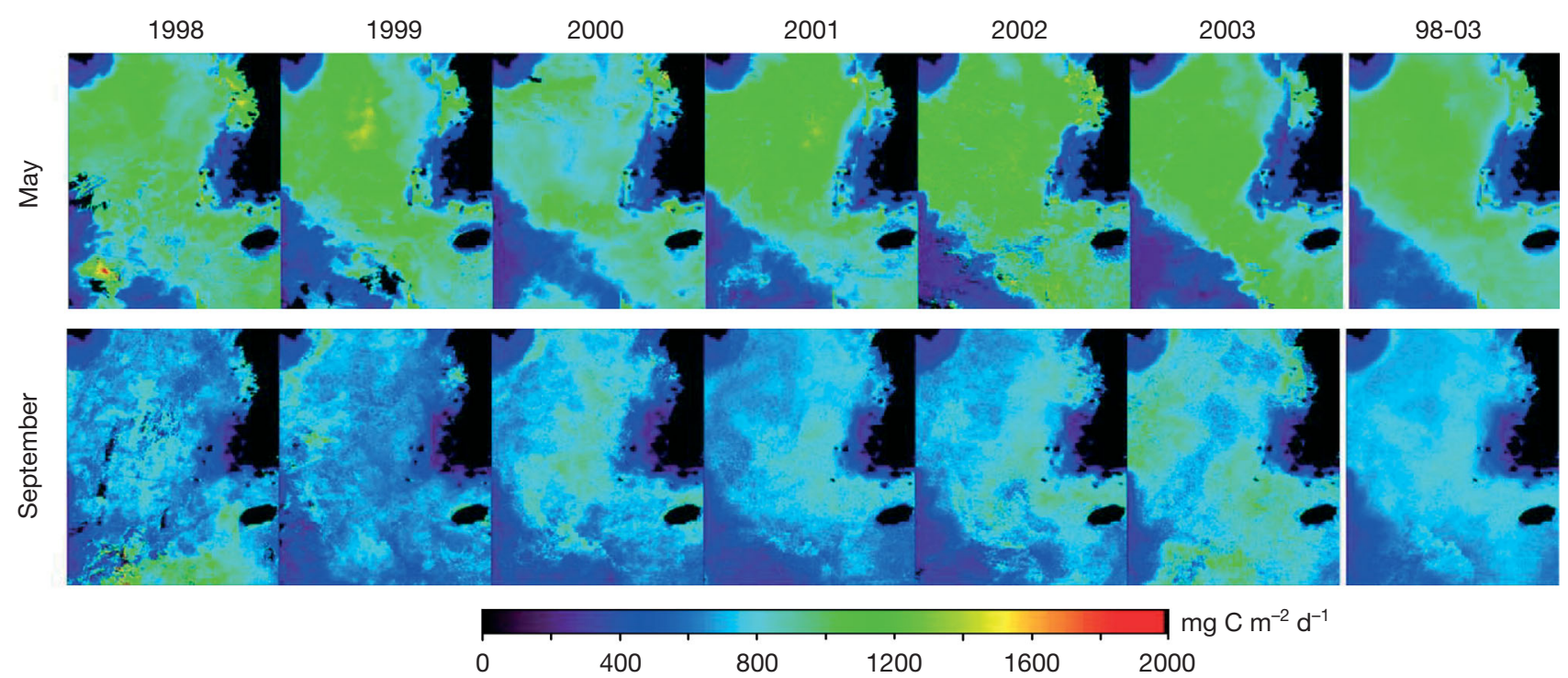

Fig. 10. Monthly composite images of primary production based on SeaWiFS from 1998 to 2003 in May and September as well as 6-year composite images (98-03 panels)

uniform profile model was underestimated by 20 to $35 \%$ in the Kuroshio Current and frontal regions of the East China Sea.

Primary production estimates would certainly benefit from more accurate information about photosynthesis-irradiance relationships (Morel et al. 1996). Studies have shown that primary production is more sensitive to changes in the $P$ - $E$ parameters than to the chlorophyll-profile parameterization (Sathyendranath et al. 1995). An error in our approach results from the aggregation of the parameters within provinces (Platt et al. 1995). The natural variability within each province is reflected in the $95 \%$ confidence intervals for the mean, which were in the range from $\pm 12 \%$ (MYS) to $\pm 54 \%$ (KCW) for $\alpha^{\mathrm{B}}$, and in the range from $\pm 13 \%$ (MYS) to $\pm 44 \%$ (KCW) for $P_{\mathrm{m}}^{\mathrm{B}}$. The main reason for uncertainty in the coastal regions is that only a small number of data points were available. According to Platt et al. (1988), measurement techniques cannot do better than $\pm 5 \%$ for $P_{\mathrm{m}}^{\mathrm{B}}$ and $\pm 20 \%$ for $\alpha^{B}$.

Spectrally- and depth-resolved primary production algorithms have been considered as benchmarks in estimating primary production (Platt et al. 1991, Kyewalyanga et al. 1992). Most studies have been conducted in open ocean waters and used a spectral model for the light field in the water column based on Case 1 waters. The Case 1 spectral model is not applicable in the Yellow Sea because large areas of the Yellow Sea are Case 2 waters. S. Son et al. (unpubl. data) showed that diffuse attenuation based on a Case 1 (chlorophyll-dependent) model underestimated $k_{\mathrm{d}}$ in Case 2 waters by a factor of 2 to 4 . Unfortunately, we had very few light measurements in the database used for this study. From 17 coincident measurements of SD and $k_{\mathrm{d}}$, we found that $k_{\mathrm{d}}=1.44 / \mathrm{SD}$ (Kirk 1994) was a reasonable relationship to use. By applying this relationship and an empirical relationship between measured SD and satellite water-leaving radiances at $555 \mathrm{~nm}$, we derived an algorithm for estimating $k_{\mathrm{d}}$. A reasonable relationship $\left(\mathrm{r}^{2}=0.78\right)$ was found between SD and SeaWiFS nLw555 at 300 stations measured within $1 \mathrm{~d}$ of the satellite overpass. We considered using the SeaWiFS K490 product, but its relationship with SD did not prove to be as good as that of the $555 \mathrm{~nm}$ water-leaving radiance. The standard algorithm for the SeaWiFS K490 is known to have large uncertainties in turbid water, especially where $\mathrm{K} 490$ is greater than $0.25 \mathrm{~m}^{-1}$ (O'Reilly et al. 2000).

The mean $k_{\mathrm{d}}$ derived from nLw555 was $0.12 \mathrm{~m}^{-1}$ in the central Yellow Sea, and varied from 0.3 to $0.38 \mathrm{~m}^{-1}$ with a maximum value of $0.76 \mathrm{~m}^{-1}$ in the coastal regions. These values were similar to results reported by S. Son et al. (unpubl. data), in which $k_{\mathrm{d}}$ in the Yellow Sea ranged from $0.09 \mathrm{~m}^{-1}$ to $0.74 \mathrm{~m}^{-1}$ with a mean of $0.20 \mathrm{~m}^{-1}$.

Errors associated with ocean color chlorophyll algorithms range from 50 to $100 \%$ in turbid waters found in near-shore areas of the Northeastern Atlantic (Hoepffner et al. 1999). Since a large part of the Yellow Sea is characterized as Case 2 waters, the current standard chlorophyll algorithm overestimates the chlorophyll concentration and consequently primary production. Therefore, we chose a local empirical algorithm for chl a concentration developed by Ahn (2004) for the Yellow Sea. Comparisons of SeaWiFS standard algorithms (OC2 and OC4) with in situ measurements in Korean waters (Moon et al. 2002, Ahn 2004) showed that the standard algorithms are suit- 
(a)
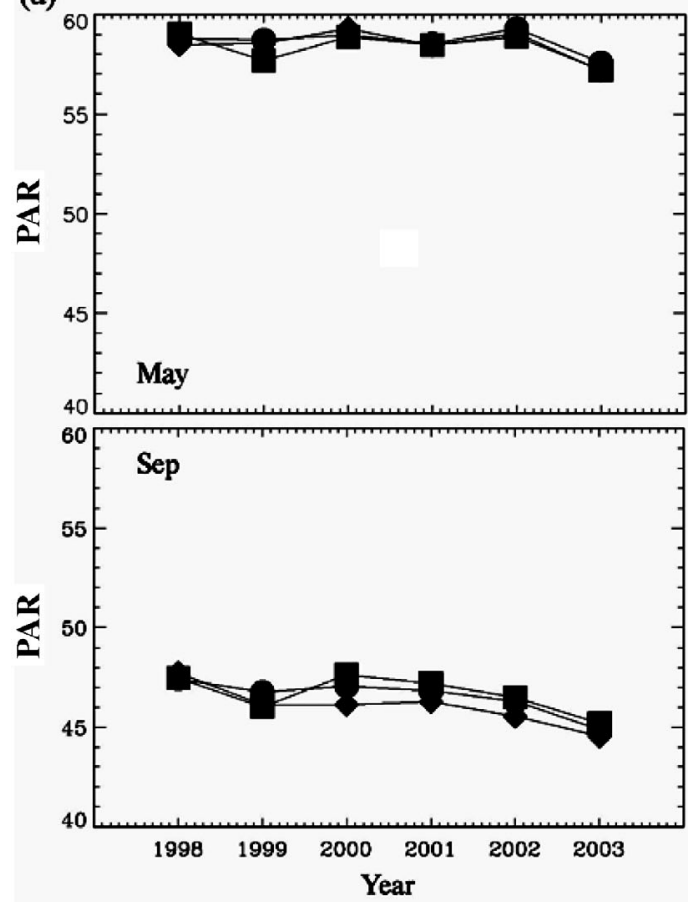

(c)

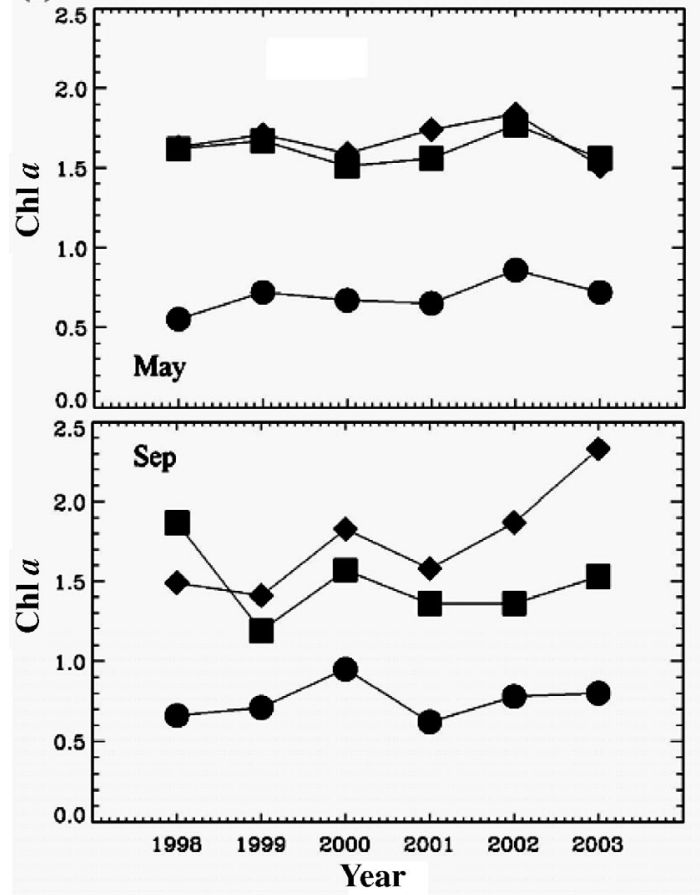

(b)
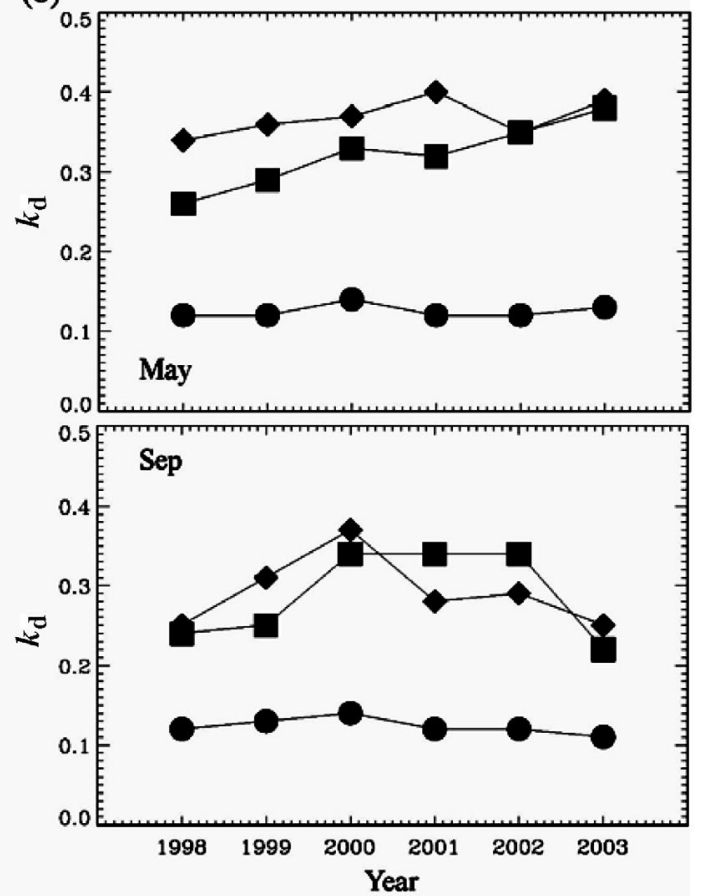

(d)

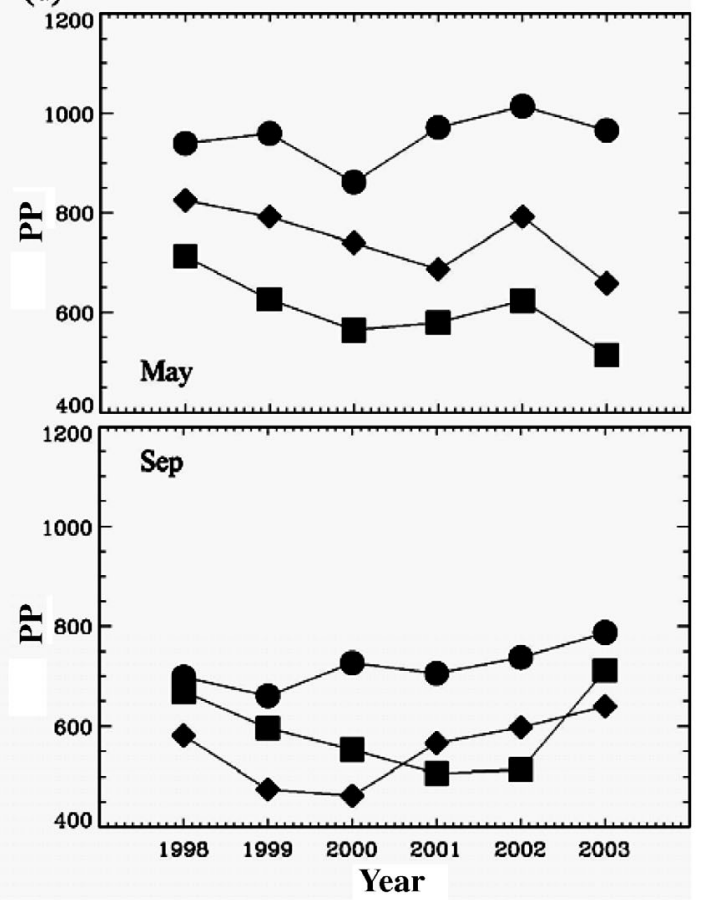

Fig. 11. Year-to-year variations of the mean values of the SeaWiFS input values in the 3 sub-regions in May and September. (a) PAR, (b) diffuse attenuation $\left(k_{\mathrm{d}}\right)$ derived from nLw555, (c) chlorophyll derived from Ahn's algorithm, and (d) daily integrated primary production (PP). $\mathbf{\square}: \mathrm{CCW}_{;} \bullet: \mathrm{MYS}_{;} \bullet: \mathrm{KCW}$

able in the Sea of Japan and the Kuroshio Current, which are characterized as Case 1 waters, but are not applicable for Case 2 waters such as the Yellow and East China Seas (root mean square [RMS] errors were $0.618 \mathrm{mg} \mathrm{m}^{-3}$ for OC2 version 3 and $0.663 \mathrm{mg} \mathrm{m}^{-3}$ for OC4). The empirical chlorophyll algorithm developed by Ahn (2004) for the Yellow Sea had a reduced RMS of $0.34 \mathrm{mg} \mathrm{m}^{-3}$; it is still a Case 1 algorithm as it does not account for variability in other optically active constituents.

In this study, we presented monthly primary production for only 2 months, May and September, because 
Table 3. Primary production in the 3 regions of the Yellow Sea

\begin{tabular}{|c|c|c|c|c|c|}
\hline \multirow{3}{*}{$\begin{array}{l}\text { Sub- } \\
\text { region }\end{array}$} & \multirow{3}{*}{$\begin{array}{l}\text { Area } \\
\times 10^{3} \\
\mathrm{~km}^{2}\end{array}$} & \multicolumn{4}{|c|}{ Mean primary production rate } \\
\hline & & \multicolumn{2}{|c|}{$\mathrm{mgC} \mathrm{m} \mathrm{C}^{-1}$} & \multicolumn{2}{|c|}{$\times 10^{4}$ ton $\mathrm{C} \mathrm{d}^{-1}$} \\
\hline & & May & Sep & May & Sep \\
\hline $\mathrm{CCW}$ & 58.9 & 590.3 & 589.3 & 3.5 & 3.5 \\
\hline MYS & 147.4 & 946.5 & 722.6 & 13.9 & 10.6 \\
\hline $\mathrm{KCW}$ & 28.9 & 734.2 & 553.7 & 2.1 & 1.6 \\
\hline Mean & & 835.6 & 672.4 & & \\
\hline Total & 235.2 & & & 19.7 & 15.8 \\
\hline
\end{tabular}

in situ data on primary production and vertical biomass distribution were available only for these months. IPP varied from 590 to $947 \mathrm{mg} \mathrm{C} \mathrm{m}{ }^{-2} \mathrm{~d}^{-1}$ (with the overall mean of $836 \mathrm{mg} \mathrm{C} \mathrm{m}^{-2} \mathrm{~d}^{-1}$ ) in May, and from 554 to $723 \mathrm{mg} \mathrm{C} \mathrm{m}^{-2} \mathrm{~d}^{-1}$ (with the overall mean of $672 \mathrm{mg} \mathrm{C}$ $\mathrm{m}^{-2} \mathrm{~d}^{-1}$ ) in September. In both months, the primary production was lower in the coastal waters and higher in the middle of the Yellow Sea. Despite higher chlorophyll concentrations, lower production resulted in coastal waters due to higher turbidity and shallow depths. The overall mean primary production was $24 \%$ higher in May than in September, largely due to the fact that PAR was $26 \%$ higher in May than September. Thus the seasonal variation of light may be an important factor in determining variations in primary production.

We calculated IPP using daily satellite images and then averaged the IPP images to form monthly composites. By applying the IPP algorithm to daily data, we avoided the problem of using averaged values in nonlinear equations (Eqs. 2 \& 3), a practice that can introduce artifacts as described in Campbell (2004). However, the use of daily satellite data has an associated clear-sky bias since all input data are from cloud-free pixels. This has a large effect on the PAR values used as input, but its effect on the derived IPP can be minimal depending on the algorithm (Campbell 2004).

There are only 2 studies that describe the distribution of chlorophyll and primary productivity over the entire Yellow Sea (Choi et al. 1995, Wu et al. 1995). Both were based on cruises made in September 1992. Choi et al. (1995) reported mean primary production to be $740 \mathrm{mg} \mathrm{C} \mathrm{m}^{-2} \mathrm{~d}^{-1}$, which is similar to our result. Wu et al. (1995) reported a much lower mean primary production (331 $\mathrm{mg} \mathrm{C} \mathrm{m}^{-2} \mathrm{~d}^{-1}$ ) for the same month and year and similar stations. The large differences between these primary production estimates may be the result of different methods used to derive the depth-integrated primary production. Choi et al. (1995) measured primary productivity using ${ }^{14} \mathrm{C}$ methods and estimated depth-integrated primary production with the formula of Platt et al. (1980). Wu et al. (1995) also measured primary production using ${ }^{14} \mathrm{C}$, but applied Cadee \& Hegeman's (1974) formula to estimate depthintegrated primary production. In addition, both studies found very different chlorophyll levels (0.16 to $3.20 \mathrm{mg} \mathrm{m}^{-3}$ with mean $0.69 \mathrm{mg} \mathrm{m}^{-3}$, Choi et al. [1995]; 0.43 to $17.43 \mathrm{mg} \mathrm{m}^{-3}$ with mean $1.362 \mathrm{mg} \mathrm{m}^{-3}$, Wu et al. [1995]), which were curiously opposite in magni-

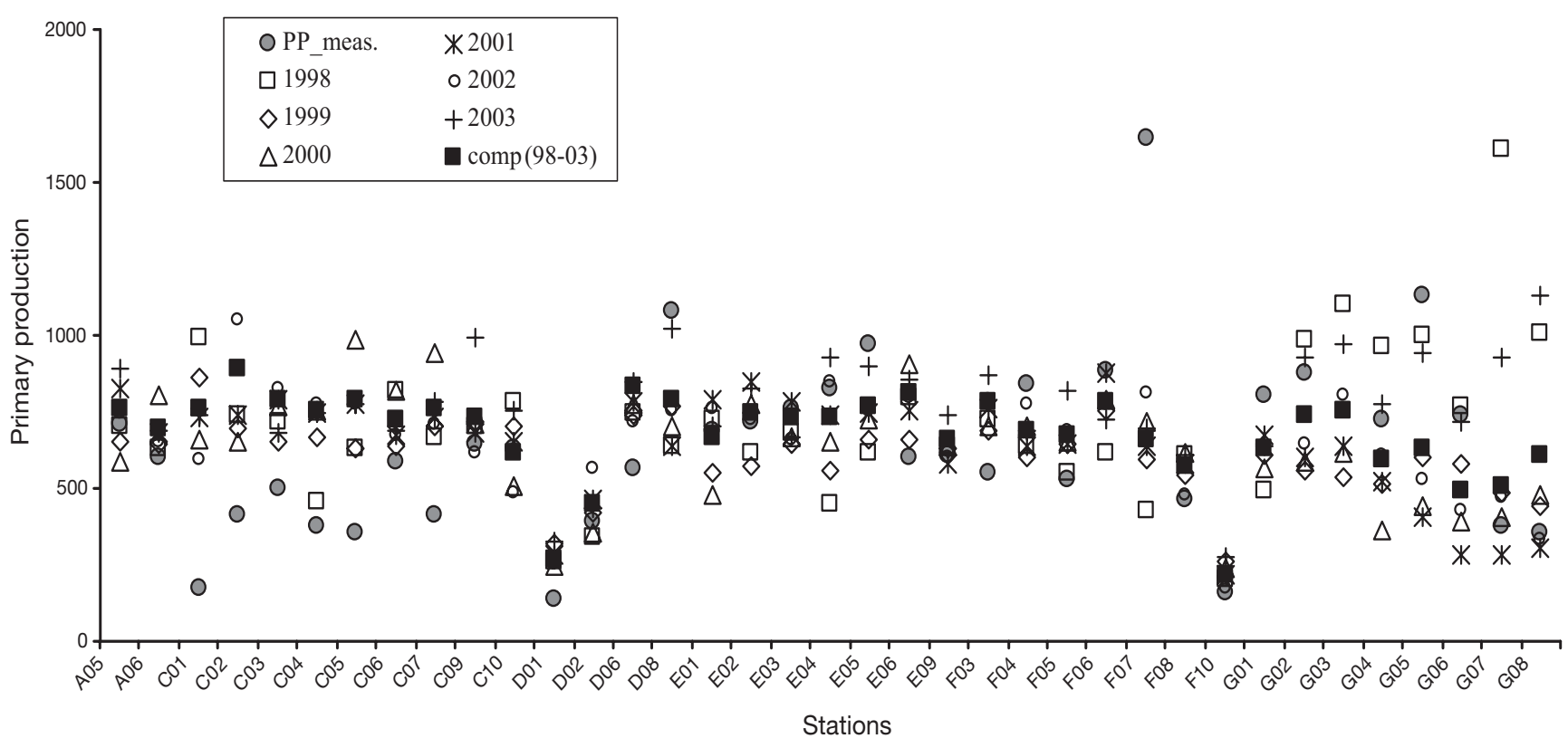

Fig. 12. The values extracted from the monthly primary production images in 1998 to 2003 compared with the measured primary production (PP) at 37 stations of the Yellow Sea cruise in September, 1992 (Choi et al. 1995) 
tude to different primary production estimates. In this study, our primary production model was based on Platt et al. (1988), and we used the data measured by Choi et al. (1995) as input data for our algorithm. Thus, our result should be comparable with that of Choi et al. (1995). In their results, the average primary production was $702 \mathrm{mg} \mathrm{C} \mathrm{m}^{-2} \mathrm{~d}^{-1}$ in offshore stratified waters and $620 \mathrm{mg} \mathrm{C} \mathrm{m}^{-2} \mathrm{~d}^{-1}$ in the Korean coastal waters. Others reported that primary production in the Kyunggi Bay was about $647 \mathrm{mg} \mathrm{C} \mathrm{m}^{-2} \mathrm{~d}^{-1}$ in September 1986 (Chung $\&$ Park 1988). These mean values are similar to our estimates: $740 \mathrm{mg} \mathrm{C} \mathrm{m}^{-2} \mathrm{~d}^{-1}$ in the middle of the Yellow Sea, and $684 \mathrm{mg} \mathrm{C} \mathrm{m}^{-2} \mathrm{~d}^{-1}$ in the Korean coastal waters.

Choi et al. (2003) measured primary production in the southeast Yellow Sea during 5 months in 1997 (February, April, August, October and December). Although it was not possible to compare their results with our estimates, which were for different months beginning in 1998, the spatial distributions of primary production were similar; both studies found lower primary production in the Kyunngi Bay and the southwestern coastal waters of Korea, and higher levels in the central waters of the Yellow Sea.

We do not have any measured primary production data to validate the satellite-derived primary production for the months of the SeaWiFS data. However, we compared primary production measured at 37 stations in September 1992 with monthly composite primary production estimates at the same stations from September 1998 to September 2003. Although the measured IPP generally fell in the range of the satellitederived IPP, about one-third of the measured IPP were below the range of the satellite estimates.

When we used the input parameters for May and September to derive primary production for other months, we estimated the annual total primary production in the Yellow Sea to have varied from 47.8 to $53.3 \times 10^{6} \mathrm{t} \mathrm{C} \mathrm{yr}^{-1}$ between 1998 and 2003, with a mean of $50.13 \times 10^{6} \mathrm{t} \mathrm{C} \mathrm{yr}^{-1}$. Clearly, we require models with better seasonal resolution before the annual production can be reliably estimated. However crude, our results provide the first synoptic maps of primary production in the Yellow Sea.

Acknowledgements. This work was supported by a NASA MODIS Instrument Team investigation contract (NAS596063) and the International Ocean Color Coordinating Group (IOCCG) Visiting Fellowship. We thank NASA SeaWiFS Project, NASA Distributed Active Archieve Center, and the OrbImage for production and distribution of the SeaWiFS data. We thank Drs. Shubha Sathyendranath, Trevor Platt, and 3 anonymous reviewers for valuable comments. We also thank Dr. YuHwan Ahn for kindly providing the chlorophyll algorithm and Jisoo Park for contribution to collecting in situ measurements on the cruises.

\section{LITERATURE CITED}

Ahn YH (2004) Study on prediction of oceanographic variability of the Yellow Sea (the second phase). The Korea Ocean Research \& Development Institute Report, BSPN 50900-1627-1

Antoine D, Morel A (1996) Ocean primary production 2. Estimation at global scale from satellite (coastal zone color scanner) chlorophyll. Global Biogeochem Cycles 10:57-69

Antoine D, Morel A, Andre J (1995) Algal pigment distribution and primary production in the eastern Mediterranean as derived from coastal zone color scanner observations. J Geophys Res 100:16193-16209

Balch W, Evans R, Brown J, Feldman G, McClain C, Esaias W (1992) The remote sensing of ocean primary productivity: use of a new data compilation to test satellite algorithms. J Geophys Res 97:2279-2293

Beardsley RC, Limeburner R, Le K, Hu D, Cannon GA, Pashinski DJ (1983) Structure of the Changjiang plume in the East China Sea during June 1980. Proc Int Symp Sedimentation on the Continental Shelf, Spec Ref East China Sea, China Ocean Press, Beijing, p 265-284

Beardsley RC, Limeburner R, Yu H, Cannon GA (1985) Discharge of the Changjiang (Yangtze River) into the East China Sea. Cont Shelf Res 4:57-76

Behrenfeld M, Falkowski P (1997) Photosynthetic rates derived from satellite-based chlorophyll concentration. Limnol Oceanogr 42:1-20

Cadee GC, Hegeman J (1974) Primary production of phytoplankton in the dutch Wadden sea. Neth J Sea Res 8: $240-259$

Campbell J (2004) Issues linked to the use of binned data in models: an example using primary production. Antoine D (ed) Guide to the Creation and Use of Ocean-Colour, Level-3, Binned Data Products. Rep No. 4, IOCCG, Dartmouth, p 23-37

Choi JK (1991) The influence of the tidal front on primary productivity and distribution of phytoplankton in the mid-eastern coast of Yellow Sea. J Oceanogr Soc Korea 26:223-241

Choi JK, Shim JH (1986) The ecological study of phytoplankton in Kyeonggi Bay, Yellow Sea: II. Light intensity, transparency, suspended substances. J Oceanogr Soc Korea 21: 101-109

Choi JK, Noh JH, Shin KS, Hong KH (1995) The early autumn distribution of chlorophyll-a and primary productivity in the Yellow Sea, 1992. Yellow Sea 1:68-80

Choi JK, Noh JH, Cho SH (2003) Temporal and spatial variation of primary production in the Yellow Sea. Proc Yellow Sea Int Symp, Ansan, South Korea, p 103-115

Chung KH, Park YC (1988) Primary production and nitrogen regeneration by macrozooplanton in the Kyunggi Bay, Yellow Sea. J Oceanogr Soc Korea 23:194-206

Gong GC, Liu GJ (2003) An empirical primary production model for the East China Sea. Cont Shelf Res 23:213-224

Hoepffner N, Sturm B, Finenko Z, Larkin D (1999) Depthintegrated primary production in the eastern tropical and subtropical North Atlantic basin from ocean colour imagery. Int J Remote Sens 20:1435-1456

Kang YS (1992) Primary productivity and assimilation number in the Kyonggi bay and the mid-eastern coast of Yellow Sea. J Oceanogr Soc Korea 27:237-246

Kirk JTO (1994) Light and photosynthesis in aquatic ecosystems, 2nd edn. Cambridge University Press, Cambridge, p119-120

Kyewalyanga M, Platt T, Sathyendranath S (1992) Ocean pri- 
mary production calculated by spectral and broad-band models. Mar Ecol Prog Ser 85:171-185

Lewis M, Cullen J, Platt T (1983) Phytoplankton and thermal sturucture in the upper ocean: consequences of nonuniformity in chlorophyll profile. J Geophys Res 88:2565-2570

Longhurst A, Sathyendranath S, Platt T, Caverhill C (1995) An estimate of global primary production in the ocean from satellite radiometer data. J Plankton Res 17: $1245-1271$

Mask AC, O'Brien JJ, Preller R (1998) Wind-driven effects on the Yellow Sea warm current. J Geophys Res 103: 30713-30729

Moon JE, Ahn YH, Choi JK (2002) Compatible study on the SeaWiFS chlorophyll standard algorithm in Korean waters. Proceedings of the autumn meeting, Korean Society of Oceanography, Nov 14-15, 2002, Seoul, p 103-107

Morel A, Berthon JF (1989) Surface pigments, algal biomass profiles, and potential production of the euphotic layer: relationships reinvestigated in view of remote-sensing applications. Limnol Oceanogr 34:1545-1562

Morel A, Prieur L (1977) Analysis of variations in ocean color. Limnol Oceanogr 22:709-722

Morel A, Antoine D, Babin M, Dandonneau Y (1996) Measured and modeled primary production in the northeast Atlantic (EUMELI JGOFS program): the impact of natural variations in photosynthetic parameters on model predictive skill. Deep-Sea Res I 43:1273-1304

Ning X, Liu Z, Cai Y, Fang M, Chai F (1998) Physicobiological oceanographic remote sensing of the East China Sea: satellite and in situ observations. J Geophys Res 103: 21623-21635

O'Reilly JE, Maritorena S, O'Brien MC, Siegel DA and 21 others (2000) SeaWiFS postlaunch calibration and validation analyses, Part 3. In: Hooker SB, Firestone ER (eds) NASA technical memorandum 2000-206892, Vol 11. NASA Goddard Space Flight Center, Greenbelt, MD

Park J (2000) Vertical distribution and primary productivity of phytoplankton in the Yellow Sea in spring time. MSc thesis, Inha University, Incheon

Pernetta JC, Milliman JD (1995) Land-ocean interactions in the coastal zone implementation plan. International Geosphere-Biosphere Program Report No. 33, Stockholm

Platt T, Sathyendranath S (1988) Oceanic primary production: estimation by remote sensing at local and regional scales. Science 241:1613-1620

Platt T, Gallegos C, Harrison WG (1980) Photoinhibition of

Editorial responsibility: Otto Kinne (Editor-in-Chief), Oldendorf/Luhe, Germany photosynthesis in natural assemblages of marine phytoplankton. J Mar Res 38:687-701

Platt T, Sathyendranath S, Caverhill C, Lewis M (1988) Ocean primary production and available light: further algorithms for remote sensing. Deep-Sea Res 35:855-879

Platt T, Caverhill C, Sathyendranath S (1991) Basin-scale estimates of oceanic primary production by remote sensing: the North Atlantic. J Geophys Res 96:15147-15159

Platt T, Sathyendranath S, Longhurst A (1995) Remote sensing of primary production in the ocean: promise and fulfillment. Phil Trans R Soc Lond B 348:191-202

Sathyendranath S, Platt T (1988) The spectral irradiance field at the surface and in the interior of the ocean: a model for applications in oceanography and remote sensing. J Geophys Res 93:9270-9280

Sathyendranath S, Platt T (1989) Remote sensing of ocean chlorophyll: consequence of nonuniform pigment profile. Appl Opt 28:490-495

Sathyendranath S, Platt T (1993) Underwater light field and primary production: application to remote sensing. In: Barale V, Schlittenhardt PM (eds) Ocean colour: theory and applications in a decade of CZCS experience. Kluwer Academic, Brussels, p 79-93

Sathyendranath S, Longhurst A, Caverhill C, Platt T (1995) Regionally and seasonally differentiated primary production in the North Atlantic. Deep-Sea Res 42:1773-1802

Schubel JR, Shen HT, Park MJ (1984) A comparison of some characteristic sedimentation processes of estuaries entering the Yellow Sea. In: Marine geology and physical processes of the Yellow Sea. Proc Korea-USA Seminar \& Workshop, Seoul, p 286-308

Siswanto E, Ishizaka J, Yokouchi K (2004) Estimating chlorophyll vertical profiles from satellite data and the implication to primary production in Kuroshio front of the East China Sea. J Oceanogr 61:575-589

Steeman Nielsen E (1952) The use of radioactive carbon (C14) for measuring organic production in the sea. J Cons Int Explor Mer 18:117-140

Su J (1998) Circulation dynamics of the China Seas North of $18^{\circ}$ N. In: Robinson AR, Brink KH (eds) The sea, Vol 11. Wiley, New York, p 483-505

Wu Y, Guo Y, Zhang Y (1995) Distributional characteristics of chlorophyll-a and primary productivity in the Yellow Sea. Yellow Sea 1:81-92

Yoo S, Shin K (1995) Primary productivity properties in the nearshore region of Taean Peninsula. Ocean Res 17:91-99

Submitted: December 21, 2004; Accepted: May 26, 2005

Proofs received from author(s): October 18, 2005 